\title{
Inhibition of Protein Secretion by Cerulenin in Bacillus subtilis
}

\author{
By PEKKA MÄNTS ̈̈L Ä \\ Department of Biochemistry, University of Turku, 20500 Turku 50, Finland
}

(Received 9 November 1981; revised 20 April 1982)

\begin{abstract}
Cerulenin at a concentration of $10 \mu \mathrm{g} \mathrm{ml}^{-1}$ only slightly inhibited growth of Bacillus subtilis YY88 while at $50 \mu \mathrm{g} \mathrm{ml}^{-1}$ it inhibited the growth rate by $20-35 \%$ in complex media, and by 50 $60 \%$ in mineral medium containing a single carbon source. Cerulenin $\left(50 \mu \mathrm{g} \mathrm{ml}^{-1}\right)$ only partially prevented the secretion of $\alpha$-amylase, proteases and levansucrase when added to bacteria growing in complex medium, but completely prevented the secretion of these enzymes in the mineral medium. Lower concentrations of cerulenin $\left(10 \mu \mathrm{g} \mathrm{ml}^{-1}\right)$ inhibited the secretion of the enzymes in the mineral medium by up to $40 \%$. When the cells were incubated with $\mathrm{L}_{-}\left[{ }^{35} \mathrm{~S}\right]-$ methionine (plus a complete amino acid mixture) in the presence of cerulenin $\left(50 \mu \mathrm{g} \mathrm{ml}^{-1}\right)$, protein secretion was lowered by $68 \%$. Cerulenin inhibited translocation of membrane-bound forms of the secreted enzymes to $18 \%$ of the control value and the incorporation of radioactive methionine into membranes to $46 \%$. These results suggest that the membrane-bound forms of secreted proteins play an important role in the secretion process in $B$. subtilis.
\end{abstract}

\section{INTRODUCTION}

Several reports suggest that exported bacterial proteins have membrane-bound forms which are tightly associated with a phospholipid moiety (Yamamoto \& Lampen, 1976; Mäntsälä \& Zalkin, 1979, 1980; Kennedy \& Lennarz, 1979; Caulfield et al., 1979). The exact role of the membrane-bound forms is still obscure but there is evidence supporting the idea that they serve as intermediates during transport. Nagata et al. (1974) and Mäntsälä \& Zalkin (1979) concluded from the rate of formation of $\alpha$-amylase in Bacillus subtilis that there was a cell-bound precursor of the extracellular enzyme. Similarly, membrane-bound lipase may be an intermediate in the secretion of extracellular lipase (Kennedy \& Lennarz, 1979).

Cerulenin is an antibiotic which is a specific inhibitor of fatty acid synthetase (Vance et al., 1972). Inhibition of lipid synthesis prevents secretion of levansucrase (Caulfield et al., 1979), $\alpha$ amylase, protease (Paton et al., 1980) and penicillinase (Fishman et al., 1978) in bacilli. Paton et al. (1980) reported that cerulenin only inhibits the formation of secreted enzymes in Bacillus amyloliquefaciens, without having any effect on the synthesis of membrane proteins. However, they did not study the synthesis of membrane-bound forms of the secreted proteins. In order to understand the mechanism of protein secretion it is important to know whether the formation and assembly of the membrane-bound forms are influenced by cerulenin in the same way as the secreted forms. In the present paper on the secretion of $\alpha$-amylase, proteases and levansucrase by $B$. subtilis a study of these effects is described.

\section{METHODS}

Bacteria. Bacillus subtilis YY88 (purB6 metB5 str amyEm amyR2 proL pap-9) was generously provided by Dr Y. Yoneda, University of Tokyo.

Growth conditions. The bacteria were cultured in a complex medium $(0.8 \%$ nutrient broth or $0.8 \%$ Casamino acids) and in a mineral medium which contained minimal salts (Dawes \& Mandelstam, 1970), sucrose $\left(60 \mathrm{~g} \mathrm{l}^{-1}\right)$ and L-methionine, adenine and guanine $\left(40 \mu \mathrm{g} \mathrm{ml}^{-1} \mathrm{each}\right)$ to provide for the auxotrophic requirements. In some experiments Bacto-peptone ( $\left.3 \mathrm{~g} \mathrm{I}^{-1}\right)$ was added to the mineral medium to stabilize the secreted proteins. The effect of cerulenin was studied by adding the antibiotic (to $10-50 \mu \mathrm{g} \mathrm{m}^{-1}$ ) to the medium. Washed cells for labelling experiments were obtained by culturing strain YY88 in the complex medium. After $10 \mathrm{~h}$ shaking at $37^{\circ} \mathrm{C}$ 
(Klett reading 230 , employing filter 62$)$ the cells were collected by centrifugation $(6000 \mathrm{~g}, 15 \mathrm{~min})$ and washed three times with cold minimal salts solution (Dawes \& Mandelstam, 1970).

Secretion of labelled proteins. The washed cells $\left(34 \mathrm{mg}\right.$ dry wt) were shaken for $2 \mathrm{~h}$ at $37^{\circ} \mathrm{C}$ in a mixture $(50 \mathrm{ml})$ containing: L-amino acids, $0.2 \mathrm{~mm}$ each except L-methionine which was $0 \cdot 05 \mathrm{mM}$ (containing $5 \cdot 2 \mathrm{MBq} \mathrm{L}-\left[{ }^{35} \mathrm{~S}\right]-$ methionine); adenine and guanine, $40 \mu \mathrm{g} \mathrm{ml}^{-1}$ : and the minimal salts solution (Dawes \& Mandelstam, 1970) with $\mathrm{FeCl}_{3}$ omitted, which prevented cell growth. The incubations were carried out with or without cerulenin $\left(50 \mu \mathrm{g} \mathrm{ml}^{-1}\right)$. The cells were removed from the culture by centrifugation $(6000 \mathrm{~g}, 15 \mathrm{~min})$ and the proteins precipitated from the supernatant by adding TCA to a final concentration of $10 \%(\mathrm{w} / \mathrm{v})$. TCA was removed by washing the pellet three times with ethanol and twice with diethyl ether.

Extraction of the labelled membrane proteins. After labelling with $\mathrm{L}-\left[{ }^{35}\right.$ S $]$ methionine the cells were washed three times with minimal salts solution containing $1 \mathrm{M}-\mathrm{NaCl}$, suspended in this solution and disrupted in a French press $(60 \mathrm{MPa})$. The cells and cell debris were removed by centrifugation $(2000 \mathrm{~g}, 5 \mathrm{~min})$ and the membranes were pelleted from the supernatant by further centrifugation $(26000 \mathrm{~g}, 30 \mathrm{~min})$ and washed once with $50 \mathrm{ml}$ of $50 \mathrm{~mm}$ Tris $/ \mathrm{HCl} / 10 \mathrm{~mm}-\mathrm{CaCl}_{2}, \mathrm{pH} 7 \cdot 5$. The membranes were resuspended in $4 \mathrm{ml}$ of the same Tris buffer and shaken for $30 \mathrm{~min}$ at $37^{\circ} \mathrm{C}$ in the presence of $0.5 \%(\mathrm{v} / \mathrm{v})$ Triton $\mathrm{X}-100$. The insoluble fraction was removed by centrifugation $(26000 \mathrm{~g}, 30 \mathrm{~min})$. The $\alpha$-amylase, alkaline protease and neutral protease were precipitated from the supernatant by adding anti- $\alpha$-amylase, anti-alkaline protease, anti-neutral protease and Staphylococcus aureus cells as previously described (Kessler, 1975; Mäntsälä \& Zalkin, 1979; Reiners et al., 1978). After antibody treatment the remaining proteins were precipitated by adding TCA up to $10 \%(\mathrm{w} / \mathrm{v})$. After centrifugation the remaining TCA was removed from the precipitate by washing with ethanol and diethyl ether as above.

Enzyme assays. $\alpha$-Amylase was assayed as described by Yamaguchi et al. (1969). Alkaline protease and neutral protease were assayed using ${ }^{125}$ I-labelled casein as the substrate (Mäntsälä \& Zalkin, 1980). Levansucrase was determined using a $\left[{ }^{1+} \mathrm{C}\right]$ glucose-sucrose exchange reaction (Chambert \& Gonzy-Treboul, 1976).

One unit of $\alpha$-amylase is defined as the amount of enzyme causing a $-\Delta A_{700}$ of $1.0 \mathrm{~h}^{-1}$ at $37^{\circ} \mathrm{C}$. One unit of protease is defined as the amount of enzyme causing the release of 2200 c.p.m. of ${ }^{125} \mathrm{I} \mathrm{min}^{-1}$ at $37^{\circ} \mathrm{C}$ (over $95 \%$ counting efficiency). One unit of levansucrase is defined as the amount of enzyme causing exchange of $1 \mu \mathrm{mol}$ glucose $\mathrm{h}^{-1}$ at $37^{\circ} \mathrm{C}$.

Analytical methods. Analysis of the proteins was performed by PAGE in the presence of $0 \cdot 1 \%(\mathrm{w} / \mathrm{v})$ SDS using a 5 to $20 \%(\mathrm{w} / \mathrm{v})$ polyacrylamide gradient gel according to the method of Laemmli \& Favre (1973). In the case of labelled proteins fluorography was as described by Bonner \& Laskey (1974). For molecular weight determination, the following proteins were used for calibration: chymotrypsinogen (mol. wt 25000 ), yeast alcohol dehydrogenase $(37000)$, ovalbumin (43000), Escherichia coli glutamate dehydrogenase $(51000)$ and bovine serum albumin $(67000)$.

\section{RESULTS}

\section{Effect of cerulenin on the secretion of $\alpha$-amylase, proteases and levansucrase}

The effect of cerulenin on protein secretion was studied in complex medium (nutrient broth or Casamino acids, $\left.8 \mathrm{~g} \mathrm{l}^{-1}\right)$ and in mineral medium containing sucrose $\left(60 \mathrm{~g}^{-1}\right)$. The effect of the antibiotic was quite different in the two types of medium. In the complex medium, at $50 \mu \mathrm{g} \mathrm{ml}^{-1}$, it decreased biomass formation by $20-35 \%$, but in the mineral medium by $50-60 \%$. Export of levansucrase, $\alpha$-amylase and proteases was completely prevented by cerulenin $\left(50 \mu \mathrm{g} \mathrm{m}^{-1}\right)$ in the mineral medium whereas in the complex media the export of proteins continued, although more slowly (results not shown). A lower concentration of cerulenin $\left(10 \mu \mathrm{g} \mathrm{ml}^{-1}\right)$ only slightly inhibited growth but inhibited secretion of $\alpha$-amylase, levansucrase and proteases in the minimal medium by 35,40 and $35 \%$, respectively (Fig. 1). The effect of cerulenin on growth rate or protein secretion was not detected earlier than about $1 \mathrm{~h}$ after the addition.

The SDS-polyacrylamide gel of the secreted proteins from the culture grown in mineral medium containing sucrose and Bacto-peptone is shown in Fig. 2. The addition of Bactopeptone was found to protect all of the secreted proteins against proteolysis. Cerulenin $\left(50 \mu \mathrm{g} \mathrm{ml}^{-1}\right)$ reduced biomass production by $34 \%$ and decreased the amounts of the secreted proteins by $75 \%$ in this medium (results not shown). Because the antibiotic decreased growth only by one-third the gel shows the approximate difference in amounts of secreted proteins in the cultures grown with or without cerulenin. 


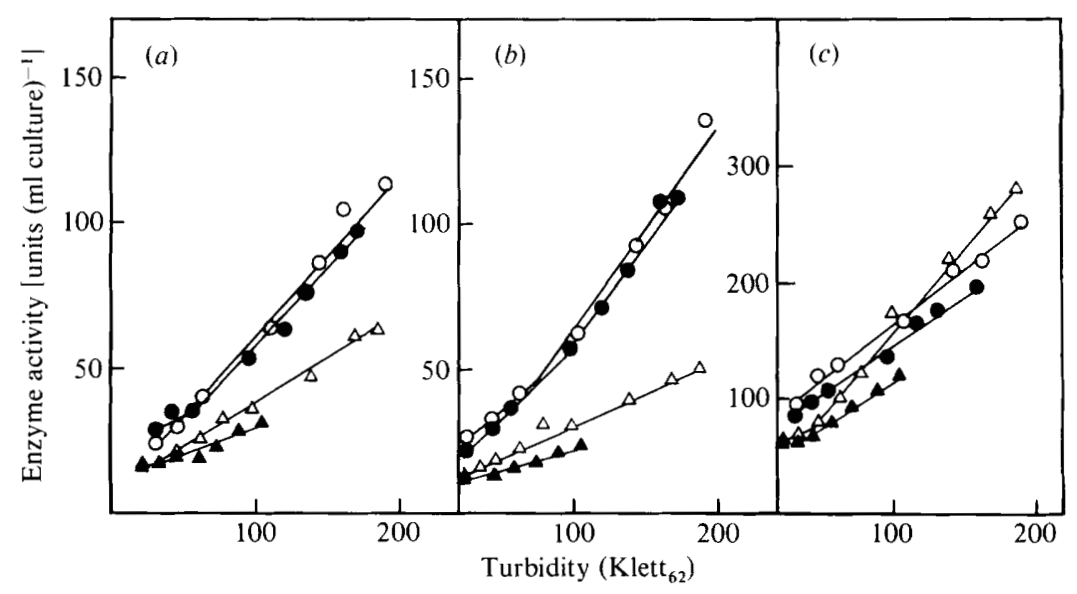

Fig. 1. Effect of cerulenin on the secretion of $(a) \alpha$-amylase, $(b)$ proteases and $(c)$ levansucrase. Bacillus subtilis YY88 was grown in nutrient broth $(\mathrm{O})$, nutrient broth plus cerulenin at $10 \mu \mathrm{g} \mathrm{ml}^{-1}(\mathrm{O})$, sucrose/mineral salts $(\triangle)$ and in sucrose/mineral salts plus cerulenin at $10 \mu \mathrm{g} \mathrm{ml}^{-1}(\mathbf{\Delta})$.

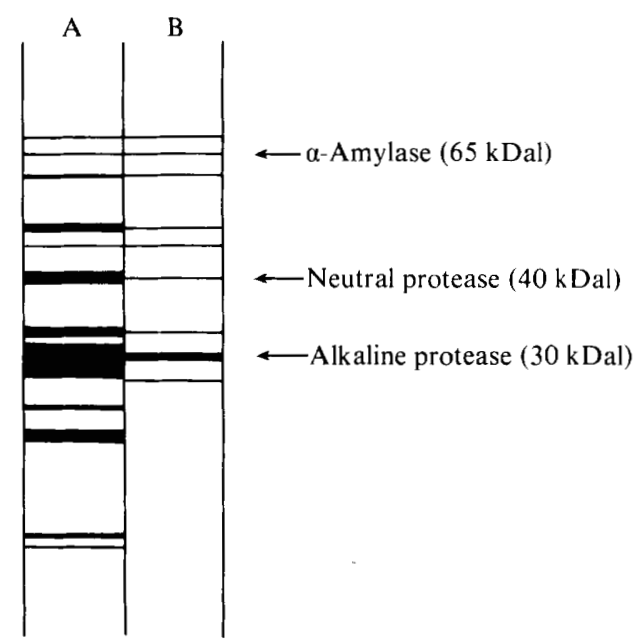

Fig. 2. Semi-diagrammatic representation of SDS-PAGE of the secreted proteins from B. subtilis YY88. The bacteria were removed after $8 \mathrm{~h}$ growth and the proteins were precipitated from the supernatants with TCA before application to the gel. Detection was with Coomassie blue. Lane A, bacteria grown with sucrose $\left(60 \mathrm{~g}^{-1}\right)$ and Bacto-peptone $\left(3 \mathrm{~g} \mathrm{l}^{-1}\right)$ in the absence of cerulenin; yield, $24 \mu \mathrm{g}$ protein. Lane B, bacteria grown in the presence of cerulenin (final concentration $50 \mu \mathrm{g} \mathrm{ml}^{-1}$ ); yield, $6 \mu \mathrm{g}$ protein.

\section{Effect of cerulenin on the activities of membrane-bound forms}

We have previously suggested that the membrane-bound forms of $\alpha$-amylase (Mäntsälä \& Zalkin, 1979) and proteases (Mäntsälä \& Zalkin, 1980) might be the intermediate forms of the secreted proteins. As shown above, cerulenin almost completely inhibited secretion in the mineral medium. If membrane-bound forms are obligatory for protein export, cerulenin might similarly affect the assembly of these protein forms. Indeed, cerulenin $\left(50 \mu \mathrm{g} \mathrm{ml}^{-1}\right)$ strongly decreased the formation or assembly of membrane-bound forms of $\alpha$-amylase, levansucrase and proteases in the mineral medium containing sucrose and Bacto-peptone (Table 1). The total activities of membrane-bound forms after $8 \mathrm{~h}$ growth were even lower than immediately after inoculation. This decrease may be due to proteolysis or disturbance in the membrane assembly 
Table 1. Effect of cerulenin on the activities of $\alpha$-amylase, proteases and levansucrase in the Triton X-100 soluble membrane fraction

The bacteria were cultured in the mineral medium containing sucrose $\left(60 \mathrm{~g}^{-1}\right)$ and Bacto-peptone $\left(3 \mathrm{~g} \mathrm{l}^{-1}\right)$ as carbon source and then washed and disrupted and the membrane vesicles solubilized as described in Methods. After centrifugation $(26000 \mathrm{~g}, 30 \mathrm{~min})$ the supernatant was assayed for enzyme activities.

$\begin{array}{lcc}\text { Enzyme } & \overbrace{\begin{array}{c}\text { With cerulenin } \\ \left(50 \mu \mathrm{g} \mathrm{ml}^{-1}\right)\end{array}}^{\begin{array}{c}\text { Specific activity } \\ \left.\text { Conits (mg protein })^{-1}\right]\end{array}} \\ \begin{array}{lcc}\alpha \text {-Amylase } \\ \text { Proteases } \\ \text { Levansucrase }\end{array} & \begin{array}{l}9 \cdot 8 \\ 135 \cdot 7\end{array} & 36 \cdot 8 \\ & 97 \cdot 0 & 45 \cdot 6\end{array}$

during growth in the presence of cerulenin. Probably the assembly of newly synthesized proteins into the membrane is prevented when lipid synthesis is inhibited by cerulenin.

No free $\alpha$-amylase, levansucrase or proteases were detected in the cytoplasm of the cells grown in the presence of cerulenin $\left(10 \mu \mathrm{g} \mathrm{ml}^{-1}\right)$. The formation and accumulation of inactive or altered $\alpha$-amylase or proteases were studied immunologically. No extra immunoprecipitable proteins were detected in the culture supernatants or in the cytoplasm of the cells grown in the presence of cerulenin when equal amounts (in activity units) of $\alpha$-amylase or protease from the cultures grown with or without cerulenin were compared (results not shown). However, the possibility that cerulenin changes the immunological properties of the proteins cannot be excluded.

\section{Effect of cerulenin on the secretion of $\mathrm{L}-\left[{ }^{35}\right.$ S] methionine labelled proteins in B. subtilis $Y Y 88$}

When the cells of $B$. subtilis YY88 were incubated in the medium containing mineral salts (without $\mathrm{FeCl}_{3}$ ), plus amino acids $[0.2 \mathrm{mM}$, except methionine which was $0.05 \mathrm{mM}(5 \cdot 2 \mathrm{MBq} \mathrm{L}$ $\left[{ }^{35} \mathrm{~S}\right]$ methionine $\left.)\right]$ they secreted several labelled proteins. When biomass formation is taken into account cerulenin $\left(50 \mu \mathrm{g} \mathrm{ml}^{-1}\right)$ decreased incorporation of $\mathrm{L}-\left[{ }^{35} \mathrm{~S}\right]$ methionine into the secreted proteins by $68 \%$. The fairly high amount of radioactivity found in the proteins secreted in the presence of cerulenin may be explained by the observation that the antibiotic does not affect protein synthesis (or cell growth during the first hour of cultivation in the type of experiment shown in Fig. 1). Results of the same kind have been reported by Petit-Glatron \& Chambert (1981) and Bocquet-Pages et al. (1981). When the secreted protein mixture was incubated with anti- $\alpha$-amylase and anti-proteases and the precipitates subjected to SDS-PAGE, three bands were seen in the gel at the positions of 30,40 and $65 \mathrm{kDal}$, corresponding to alkaline protease, neutral protease and $\alpha$-amylase (results not shown). The amounts of ${ }^{35} \mathrm{~S}$-labelled $\alpha$-amylase and proteases, however, were reduced by $76 \%$ in the medium containing cerulenin $\left(50 \mu \mathrm{g} \mathrm{ml}^{-1}\right)$.

\section{Effect of cerulenin on membrane proteins}

The amounts of radioactivity precipitated by TCA or anti- $\alpha$-amylase and anti-proteases from the Triton X-100 supernatants are presented in Table 2. Staphylococcus aureus cells alone also had some affinity for the Triton X-100 fraction. Cerulenin $\left(50 \mu \mathrm{g} \mathrm{ml}^{-1}\right)$ decreased incorporation of radioactivity into membranes to $46 \%$, of the control value, and the formation of the proteins precipitable with anti- $\alpha$-amylase and anti-proteases in the Triton X-100 fraction to $18 \%$ of the control value.

The results indicate that there is only a small amount of membrane-bound forms of $\alpha$-amylase and proteases in the cells grown in the presence of cerulenin $\left(50 \mu \mathrm{g} \mathrm{ml}^{-1}\right)$.

\section{DISCUSSION}

Cerulenin might be employed as an agent to provide evidence for the involvement of membrane-bound protein forms anchored into membranes by tight non-covalent association with the lipid moiety. This membrane form might be an intermediate in the release of exoproteins. Caulfield et al. (1979) concluded that this intermediate might be a lipid. They 
Table 2. Incorporation of radioactivity into the Triton $X-100$ soluble fraction of membranes in the presence of cerulenin

The ${ }^{35} \mathrm{~S}$-labelled membrane fragments prepared from $34 \mathrm{mg}$ dry wt cells as described in Methods were solubilized in $4 \mathrm{ml} 50 \mathrm{~mm}$-Tris $\mathrm{HCl} / 10 \mathrm{~mm}-\mathrm{CaCl}_{2} / 0 \cdot 5 \%$ (w/v) Triton X-100 buffer, $\mathrm{pH} 7 \cdot 5$, shaking for $30 \mathrm{~min}$ at $37^{\circ} \mathrm{C}$. After centrifugation the Triton X-100 supernatant was treated with a mixture of anti- $\alpha-$ amylase, anti-alkaline protease, anti-neutral protease and $S$. aureus cell suspension. After immunoprecipitation the proteins were precipitated from the supernatant by adding TCA up to $10 \%(\mathrm{w} / \mathrm{v})$.

$\begin{array}{lcc}\text { Control } & \begin{array}{c}\text { With cerulenin } \\ \left(50 \mu \mathrm{g} \mathrm{ml}^{-1}\right)\end{array} \\ \text { Fraction } & 100 & 45.8 \\ \text { atant } & 11.6 & 2.1 \\ \text { the remaining supernatant } & 85.0 & 43.7\end{array}$

* The values were calculated from the radioactivity of the Triton X-100 supernatant $(100 \%)$ which corresponds to $0.8 \mathrm{MBq}$ of $\mathrm{L}-\left[{ }^{35} \mathrm{~S}\right]$ methionine.

showed that cerulenin at a concentration that totally inhibited de novo lipid synthesis also totally inhibited the export of levansucrase in $B$. subtilis. Similar direct correlations have been demonstrated between the inhibition of lipid synthesis and the inhibition of penicillinase release in Bacillus licheniformis (Fishman et al., 1978) and of $\alpha$-amylase release in B. amyloliquefaciens (Paton et al., 1980).

Although cerulenin $\left(100 \mu \mathrm{g} \mathrm{ml}^{-1}\right)$ completely prevented growth of $B$. amyloliquefaciens it had no effect on assembly of proteins (Paton et al., 1980). Cerulenin $\left(50 \mu \mathrm{g} \mathrm{m}^{-1}\right)$ also completely prevented growth of $B$. subtilis, but at the same time decreased incorporation of $\left[{ }^{35} \mathrm{~S}\right]$ methionine into membranes. This decrease is at least partly due to reduction of the membrane-bound forms of exoproteins but there was also a decrease in other membrane proteins.

The exoproteins are synthesized as precursor forms with additional hydrophobic amino terminal signal sequences (Blobel \& Dobberstein, 1975). The signal sequence has a lysine or arginine residue which, it has been suggested, attaches the precursor protein to a negatively charged receptor site in the cytoplasmic side of the plasma membrane (Inouye \& Halegoua, 1980 ). Cerulenin might mediate its effect by disturbing or decreasing the assembly of the integral membrane proteins which may serve as the receptor sites for the signal peptide of the exoproteins. Fishman et al. (1978) have also proposed that cerulenin might affect the number of anchor places for membrane proteins.

Because $\mathrm{FeCl}_{3}$ was omitted from the mineral medium, growth was prevented at least during the first $2 \mathrm{~h}$ of incubation. However, the cells secreted extracellular proteins. This suggests that exoenzyme synthesis can take place in the complete absence of growth or in the presence of negligible growth. Halegoua et al. (1976) demonstrated that toluene-treated cells which were unable to grow still synthesized proteins. Although high concentrations of cerulenin $\left(50 \mu \mathrm{g} \mathrm{ml}^{-1}\right)$ completely stop growth the effect is not immediate and during the first $40-60 \mathrm{~min}$ of growth the cells transfer proteins to the external medium or to the cell membranes (unpublished results). It is not known why protein secretion was more sensitive to cerulenin in the mineral medium than in the complex medium, but one could speculate that during the initial phase of growth, when the effect of cerulenin is not yet detectable, $B$. subtilis produces more cells in the complex medium than in the mineral medium. Furthermore, cerulenin may inhibit the synthesis of many components already present in the complex medium. Although the incorporation of the membrane-bound forms of $\alpha$-amylase and proteases into membranes was inhibited to a greater extent than the incorporation of integral membrane proteins, these results suggest that in $B$. subtilis there might be different mechanisms for protein export across bacterial membranes and for translocation of membrane proteins from cytoplasm into membranes. This situation has been reported in the case of B. amyloliquefaciens (Paton et al., 1980).

Financial aid from the Finnish Academy, Division of Sciences, and from the Foundation of the University of Turku is gratefully acknowledged. 


\section{REFERENCES}

Blobel, G. \& Dobberstein, B. (1975). Transfer of proteins across membranes. I. Presence of proteolytically processed and unprocessed nascent immunoglobulin light chains on membrane-bound ribosomes of murine myeloma. Journal of Cell Biology 67, 835-851.

Bocquet-Pages, C., Lazdunski, C. \& Lazdunski, A. (1981). Lipid synthesis-dependent biosynthesis (or assembly) of major outer-membrane proteins of Escherichia coli. European Journal of Biochemistry 118, 105-111.

BONNER, W. M. \& LASKey, R. A. (1974). A film detection method for tritium-labelled proteins and nucleic acids in polyacrylamide gels. European Journal of Biochemistry 46, 83-88.

Caulfield, M. P., Berkeley, R. C. W., Pepper, E. A. \& Melling, J. (1979). Export of extracellular levansucrase by Bacillus subtilis: inhibition by cerulenin and quinacrine. Journal of Bacteriology 138, 345-35I.

Chambert, R. \& Gonzy-Treboul, G. (1976). Levansucrase of Bacillus subtilis: kinetic and thermodynamic aspects of transfructosylation processes. European Journal of Biochemistry 62, 55-64.

DAWES, I. W. \& MANDELSTAM, J. (1970). Sporulation of Bacillus subtilis in continuous culture. Journal of Bacteriology 103, 529-535.

Fishman, Y., Rottem, S. \& Citri, N. (1978). Evidence linking penicillinase formation and secretion to lipid metabolism in Bacillus licheniformis. Journal of Bacteriology 134, 434-439.

Halegoua, S., Hirashima, A., Sekizawa, J. \& INOUYE, M. (1976). Protein synthesis in toluenetreated Escherichia coli. Exclusive synthesis of membrane proteins. European Journal of Biochemistry 69 , 163-167.

Inouye, M. \& Halegoua, S. (1980). Secretion and membrane localization of proteins in Escherichia coli. CRC Critical Reviews in Biochemistry 7, 339-371.

KENNEDY, M. B. \& LenNARZ, W. J. (1979). Characterization of the extracellular lipase of Bacillus subtilis and its relationship to a membrane-bound lipase found in a mutant strain. Journal of Biological Chemistry 254, 1080-1089.

KESSLER, S. W. (1975). Rapid isolation of antigens from cells with a staphylococcal protein A-antibody adsorbent: parameters of the interaction of antibody-antigen complexes with protein A. Journal of Immunology 115, 1617-1624.
LAEMMLI, U. K. \& FAVRE, M. (1973). Maturation of the head of bacteriophage T4. I. DNA packing events. Journal of Molecular Biology 80, 575-599.

MÄNTSÄLÄ, P. \& ZALKIN, H. (1979). Membrane-bound and soluble extracellular $\alpha$-amylase from Bacillus subtilis. Journal of Biological Chemistry 254, 85408547.

MÄNTSÄLÄ, P. \& ZALKIN, H. (1980). Extracellular and membrane-bound proteases from Bacillus subtilis. Journal of Bacteriology 141, 493-501.

Nagata, Y., Yamaguchi, K. \& Maruo, B. (1974). Genetic and biochemical studies on cell-bound $\alpha$ amylase in Bacillus subtilis Marburg. Journal of Bacteriology 119, 425-430.

Paton, J. C., May, B. K. \& Elliott, W. H. (1980). Cerulenin inhibits production of extracellular proteins but not membrane proteins in Bacillus amyloliquefaciens. Journal of General Microbiology 118, 179187.

Petit-Glatron, M.-F. \& Chambert, R. (1981). Levansucrase of Bacillus subtilis: conclusive evidence that its production and export are unrelated to fatty-acid synthesis but modulated by membranemodifying agents. European Journal of Biochemistry 119, 603-611.

Reiners, J. J., Messenger, L. J. \& Zalkin, H. (1978). Immunological cross-reactivity of Escherichia coli anthranilate synthetase, glutamate synthase, and other proteins. Journal of Biological Chemistry 253, 1226-1233.

Vance, D., Goldberg, I., Mitsuhashi, O., Bloch, K., OMURA, S. \& Nomura, S. (1972). Inhibition of fatty acid synthetases by the antibiotic cerulenin. Biochemical and Biophysical Research Communications 48, 649-656.

Yamaguchi, K., MatsuZaki, M. \& Maruo, B. (1969). Participation of a regulator gene in the $\alpha$-amylase production of Bacillus subtilis. Journal of General and Applied Microbiology 15, 97-107.

Yamamoto, S. \& Lampen, J. O. (1976). Membrane penicillinase of Bacillus licheniformis $749 / \mathrm{C}$ : sequence and possible repeated tetrapeptide structure of the phospholipopeptide region. Proceedings of the National Academy of Sciences of the United States of America 73, 1457-1461. 